\title{
Determinan Akuntabilitas Pemerintahan Desa di Kabupaten Lombok Barat
}

\author{
Aziz Irwandi ${ }^{1}$ \\ Fakultas Ekonomi dan Bisnis \\ Universitas Mataram, Indonesia
}

\author{
Dwi Putra Buana Sakti2 \\ Fakultas Ekonomi dan Bisnis \\ Universitas Mataram, Indonesia
}

\section{Endar Pituringsih ${ }^{3}$ \\ Fakultas Ekonomi dan Bisnis \\ Universitas Mataram, Indonesia}

\begin{abstract}
Surel : aziztoke@gmail.com
ABSTRAK

Penelitian ini bertujuan untuk menganalisis Determinan Akuntabilitas Pemerintahan Desa Di Kabupaten Lombok Barat. Jumlah responden yang digunakan dalam penelitian sebanyak 60 orang yang menjabat sebagai Kepala Desa, Sekretaris Desa, Bendahara Desa, Badan Permusywaratan Desa dan Kepala Seksi di kantor Desa. Pengumpulan data dilakukan dengan kuisioner. Teknik analisis data menggunakan analisis regresi berganda. Hasil penelitian menunjukan Kompetensi Sumber Daya Manusia dan Sistem Pelaporan Akuntansi berpengaruh negatif terhadap Akuntabilitas Kinerja Pemerintahan Desa. Sedangkan Pengendalian Akuntansi dan Budaya Organisasi berpengaruh positif terhadap Akuntabilitas Kinerja Pemerintahan Desa.
\end{abstract}

Kata Kunci: Kompetensi SDM; Pengendalian Akuntansi; Sistem Pelaporan Akuntansi; Budaya Organisasi; Akuntabilitas Kinerja Pemda.

\section{Village Government Accountability Determinants in West Lombok Regency}

\section{ABSTRACT}

This study aims to analyze the determinants of village government accountability in West Lombok Regency. The number of respondents used in the study was 60 people who served as the Village Head, Village Secretary, Village Treasurer, Village Consultative Body and Section Head in the Village office. Data collection was carried out by means of a questionnaire. The data analysis technique used multiple regression analysis. The results showed that Human Resource Competence and Accounting Reporting System had a negative effect on the Accountability of Village Government Performance. Meanwhile, Accounting Control and Organizational Culture have a positive effect on the Accountability of Village Government Performance.

Keywords: HR Competencies; Accounting Controls; Accounting Reporting System; Organizational Culture; Accountability Of Local Government Performance.

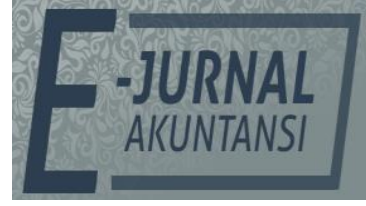

e-ISSN 2302-8556

Vol. 31 No. 5

Denpasar, Mei 2021

Hal. 1141-1153

10.24843/EJA.2021.v31.05.p06

PENGUTIPAN:

Irwandi, A., Sakti, D.P.B., \& Pituringsih, E. (2021).

Determinan Akuntabilitas Pemerintahan Desa di Kabupaten Lombok Barat. EJurnal Akuntansi, 31(5), 1141-

1153

RIWAYAT ARTIKEL:

Artikel Masuk:

20 April 2021

Artikel Diterima:

24 Mei 2021

Artikel dapat diakses : https://ojs.unud.ac.id/index.php/Akuntansi/index 


\section{PENDAHULUAN}

Akuntabilitas merupakan hal yang penting untuk dimiliki oleh entitas, baik entitas bisnis maupun pemerintah sebagai bentuk pertanggungjawaban kepada shareholders. Akuntabilitas bagi pemerintah dinilai sangat penting untuk dimiliki karena akuntabilitas akan meningkatkan kepercayaan masyarakat terhadap aktivitas yang telah dilakukan oleh pemerintah. Scott (2006) mengatakan bahwa sebagai pengelola sumber daya, maka masyarakat membutuhkan informasi yang terkait dengan aktivitas yang dilakukan oleh pengelola tersebut yakni pemerintah. Informasi ini sangat dibutuhkan oleh masyarakat guna mengetahui seberapa besar sumber daya yang dimiliki serta mengalokasikan sumber daya tersebut.

Instansi pemerintah diwajibkan untuk menyampaikan akuntabilitas kinerjanya melalui laporan kinerja instansi pemerintah secara periodik kemudian melakukan pengendalian atas akuntabilitasnya berdasarkan evaluasi atas laporan kinerjanya. Dengan demikian setiap intansi mulai dari tingkat bawah (desa), daerah maupun pusat diwajibkan melaporkan hasil kinerjanya secara periodik termasuk pemerintah desa di kecamatan Lingsar.

Dilihat dari Presentase Realisasi Fisik Program dan Kegiatan selama 1 tahun dalam tahun 2017 program yang dilaksanakan, menyatakan bahwa dari pelaksanaan Program dan Kegiatan Administrasi Perkantoran terdapat 25 kegiatan, dari 25 kegiatan ada 11 mencapai 100 persen, 14 kegiatan tidak tercapi 100 persen karena kegiatan ini terkait dengan pihak ke 3 (tiga) menyangkut jasa yaitu : (1) jasa komunikasi, air dan listrik (94,70 persen), (2) jasa pemeliharaan dan perijinan kendaraan dinas/operasional (92,33 persen), dan (3) jasa administrasi Keuangan (99,98 persen).

Selain itu, hasil pengukuran kinerja Tahun 2017 menunjukan bahwa terdapat penurunan realisasi, dimana realisasi untuk belanja langsung tahun 2016 sebesar 98.70 dan realisasi belanja langsung tahun 2017 sebesar 96.80 yaitu penurunan realisasi sebesar 1.90 persen. Hal ini disebabkan karena adanya pemotongan anggaran sejumlah Rp. 9.000.000,- dari belanja modal pengadaan kamera dan belanja pemeliharaan bangunan kantor sebesar Rp. 5.600.000. Sehingga terjadi pengurangan realisasi anggaran belanja langsung sebesar Rp.14.600.0000.

Penelitian ini merupakan pengembangan dari penelitian Yusardi (2016) terkait akuntabilitas kinerja instansi pemerintah. Perbedaan penelitian ini dibandingkan dengan penelitian Yusardi (2016) yang menjadi originalitas penelitian adalah penambahan variabel independen yaitu kompetensi sumber daya manusia dan budaya organisasi. Penelitian ini akan dilakukan di desa kecamatan Lingsar.

Menurut Mangkunegara (2005), Kompetensi adalah faktor mendasar yang dimiliki seseorang yang mempunyai kemampuan lebih, yang membuatnya berbeda dengan seseorang yang mempunyai kemampuan rata-rata atau biasa saja. Kompetensi merupakan faktor yang dapat mempengaruhi akuntabilitas. Untuk meningkatkan akuntabilitas diperlukan adanya kompetensi (Frink \& Klimoski, 2004).

Penelitian terdahulu yang terkait dengan variabel ini adalah penelitian yang dilakukan oleh Sarifudin et al., (2017) Hasil penelitiannya mengemukakan 
bahwa kompetensi aparat pengelola dana desa berpengaruh secara positif dan signifikan terhadap akuntabilitas pengelolaan dana desa. Hasil penelitian tersebut sejalan dengan Penelitian Makalalag et al., (2017). Hasil penelitiannya menyatakan bahwa kompetensi sumber daya manusia merupakan salah satu faktor yang mempengaruhi akuntabilitas pengelolaan dana desa.

Hal ini sejalan dengan teori harapan yang menyatakan bahwa, salah satu faktor yang mempengaruhi tingkat harapan atau ekspektansi seseorang yaitu informasi yang diperlukan untuk melaksanakan suatu tugas. Artinya dengan adanya informasi yang diberikan oleh perangkat desa diharapkan pihak pengguna informasi dapat menggunakan informasi tersebut untuk mengidentifikasi kelemahan-kelemahan atau area kritis dalam aspek pembangunan desa sehingga pelaksanaan pemerintahan desa dapat dilaksanakan dengan efektif, dan tujuan yang diharapkan untuk perbaikan pengelolaan kegiatan pembangunan dapat tercapai. Berdasarkan hasil penelitian di atas serta kesimpulan dari landasan teori yang ada, maka dapat ditetapkan hipotesis sebagai berikut.

$\mathrm{H}_{1}$ : Kompetensi Sumber Daya Manusia Berpengaruh Terhadap Akuntabilitas Pemerintah Desa

Pengendalian akuntansi bermanfaat dalam mengukur, mengevaluasi akuntabilitas kinerja dan dapat memotivasi manejer unit bisnis dalam mencapai tujuan yang telah di tetapkan (Bastian, 2011:459). Peningkatan perencanaan dan pengendalian terhadap aktivitas dengan cara perbaikan sistem akuntansi sektor publik diharapkan dapat membantu meningkatkan transparansi, efisiensi serta efektivitas pemerintah daerah, terutama dalam memberikan informasi dan pengungkapan atas aktifitas dan kinerja finansial pemerintah daerah. Pengendalian akuntansi menekankan pada tindakan-tindakan untuk mencegah kesalahan (kekeliruan yang tidak disengaja) dan ketidakberesan (tindakan tindakan penyimpangan yang disengaja).

Indraswari, (2010) dan Setiawan et al., (2014) menyimpulkan bahwa pengendalian akuntansi berpengaruh positif dan signifikan terhadap akuntabilitas kinerja instansi pemerintah, dimana pengendalian adalah proses yang dilakukan dalam manajemen organisasi untuk menjamin bahwa sumber daya digunakan secara ekonomis, efisien dan efektif. (Hidayattullah \& Herdjiono, 2015) memperoleh hasil penelitian bahwa kejelasan sasaran anggaran, pengendalian akuntansi dan sistem pelaporan berpengaruh positif dan signifikan terhadap akuntabilitas kinerja instansi pemerintah baik secara parsial maupun simultan. Begitu juga dengan penelitian Erwin (2013) yang menjelaskan bahwa kejelasan sasaran anggaran dan pengendalian akuntansi berpengaruh positif dan signifikan terhadap akuntabilitas kinerja instansi pemerintah baik secara parsial maupun simultan pada Kabupaten Jember.

Hasil penelitian ini sejalan dengan Stewardship theory Donaldson dan Davis (1991) menggambarkan bahwa tidak ada suatu keadaan situasi para manajemen termotivasi untuk tujuan-tujuan individu melainkan lebih fokus untuk tujuan sasaran utama yaitu kepentingan organisasi. Dengan kata lain, stewardship theory memandang bahwa manajemen dapat berperilaku baik untuk kepentingan publik dan umumnya maupun stakeholders pada khususnya (Daniri 2005). 
Berdasarkan uraian di atas dapat ditarik suatu hipotesis hubungan antara pengendalian akuntansi dan akuntabilitas kinerja sebagi berikut.

$\mathrm{H}_{2}$ : Pengendalian Akuntansi Berpengaruh Positif terhadap Akuntabilitas

Pemerintah Desa.

Sistem pelaporan merupakan laporan yang menggambarkan sistem pertanggungjawaban dari bawahan (pimpinan unit anggaran) kepada atasan (kepala bagian anggaran). Sistem pelaporan yang baik diperlukan agar dapat memantau dan mengendalikan kinerja manajerial dalam mengimplementasikan anggaran yang telah ditetapkan. Cara-cara yang dilakukan perusahaan untuk memanage stakeholdernya tergantung pada strategi yang di adopsi perusahaan baik strategi aktif maupun pasif. Salah satunya melalui penyusunan laporan keuangan. Penyusunan laporan keuangan terbukti mampu meningkatkan kepercayaan para pemangku kepentingan terhadap manajemen.

Dengan demikian, maka keberadaan suatu perusahaan sangat dipengaruhi oleh dukungan yang diberikan oleh stakeholder kepada perusahaan tersebut. Stakeholder dan Organisasi saling mempengaruhi, hal ini dapat dilihat dari hubungan sosial keduanya yang berbentuk responsibilitas dan akuntabilitas. Oleh karena itu organisasi memiliki akuntabilitas terhadap stakeholdernya. Sifat dari akuntabilitas itu di tentukan dengan hubungan antara stakeholder dan organisasi

Penelitian Hidayattullah \& Herdjiono, (2015) "Pengujian persial terhadap sistem pelaporan berpengaruh positif signifikan terhadap akuntabilitas kinerja instansi pemerintah" Anjarwati, (2012) menyimpulkan bahwa sistem pelaporan berpengaruh positif terhadap akuntabilitas kinerja instansi pemerintah Tegal dan Pemalang, didukung pula dengan penelitian Indraswari, (2010) menunjukkan hasil yang sama, karena dengan adanya sistem pengelolaan keuangan daerah yang mencakup sistem pelaporan, akan menciptakan pengelolaan keuangan yang transparan dan akuntabel, dimana sistem pelaporan yang baik akan mencantumkan penjelasan mengenai penyebab terjadinya penyimpangan, tindakan yang diambil untuk mengoreksi penyimpangan yang tidak menguntungkan dan waktu yang dibutuhkan agar tindakan koreksi lebih efektif. Berdasarkan dari tinjauan paparan di atas dan kesimpulan dari landasan teori yang ada, maka dirumuskan hipotesis sebagai berikut.

$\mathrm{H}_{3}$ : Sistem Pelaporan Berpengaruh Terhadap Akuntabilitas Pemerintah Desa.

Budaya organisasi yang baik tentunya akan mempengaruhi kualitas pelayanan publik yang baik pula. Dalam organisasi tentunya banyak faktor yang mempengaruhi seseorang untuk mencapai tujuannya, sedangkan jalannya organisasi dipengaruhi oleh perilaku banyak individu yang memiliki kepentingan masing-masing. Oleh sebab itu, budaya organisasi sangat penting, karena merupakan kebiasaan-kebiasaan yang ada dalam organisasi. Kebiasaankebiasaan yang baik ini di harapkan dapat meningkatkan kinerja pada organisasi.

Hal ini sejalan dengan teori harapan yang mengatakan bahwa karyawankaryawan akan termotivasi untuk mengeluarkan tingkat usaha yang tinggi ketika mereka yakin bahwa usaha tersebut akan menghasilkan penilaian kinerja yang baik, dan pada gilirannya menghasilkan penghargaan-penghargaan 
organisasional. Dengan demikian, maka budaya organisasi akan terbentuk pada organisasi sejalan dengan apa yang di yakini oleh perangkat pemerintahan pada suatu organisasi. Penghargaan yang diterima karena kinerja yang tinggi akan membentuk nilai-nilai pada organisasi yang akan memberikan rasa adil atas apa yang dikerjakan sesuai kewajiban dan tanggung jawab.

Nurviasari \& Riharjo, (2016) hasil penelitiannya mengemukakan bahwa budaya organisasi berpengaruh positif terhadap akuntabilitas kinerja instansi Pemerintah Kota Surabaya. Hasil penelitian ini mendukung penelitian yang dilakukan Nurkhamid, (2008) menunjukkan bahwa budaya organisasi berpengaruh positif terhadap pengembangan sistem pengukuran kinerja, akuntabilitas kinerja dan penggunaan informasi kinerja. Artinya semakin baik budaya organisasi maka semakin baik pula kinerja yang dicapai. Sehingga budaya organisasi dapat mempengaruhi cara karyawan dalam bertingkah laku, cara menggambarkan pekerjaan, dan cara bekerja dengan karyawan lain. Dalam setiap instansi pemerintah, budaya organisasi selalu diharapkan baik karena baiknya budaya organisasi akan berhubungan dengan berhasil tidaknya instansi pemerintah agar mencapai tujuannya. Berdasarkan dari tinjauan paparan di atas kesimpulan dari landasan teori yang ada, maka dirumuskan hipotesis sebagai berikut.

$\mathrm{H}_{4}$ : Budaya Organisasi Berpengaruh Positif Terhadap Akuntabilitas Pemerintah Desa.

Berdasarkan hasil penelitian terdahulu dan landasan teori yang telah diuraikan, peneliti mengidentifikasikan 5 (lima) variabel independen, yaitu Kompetensi Sumber Daya Manusia, Pengendalian Akuntansi, Sistem Pelaporan dan Budaya Organisasi yang diperkirakan berpengaruh terhadap Akuntabilitas Pemerintah Desa variabel dependen. Model penelitian ini dapat dilihat pada Gambar 1.

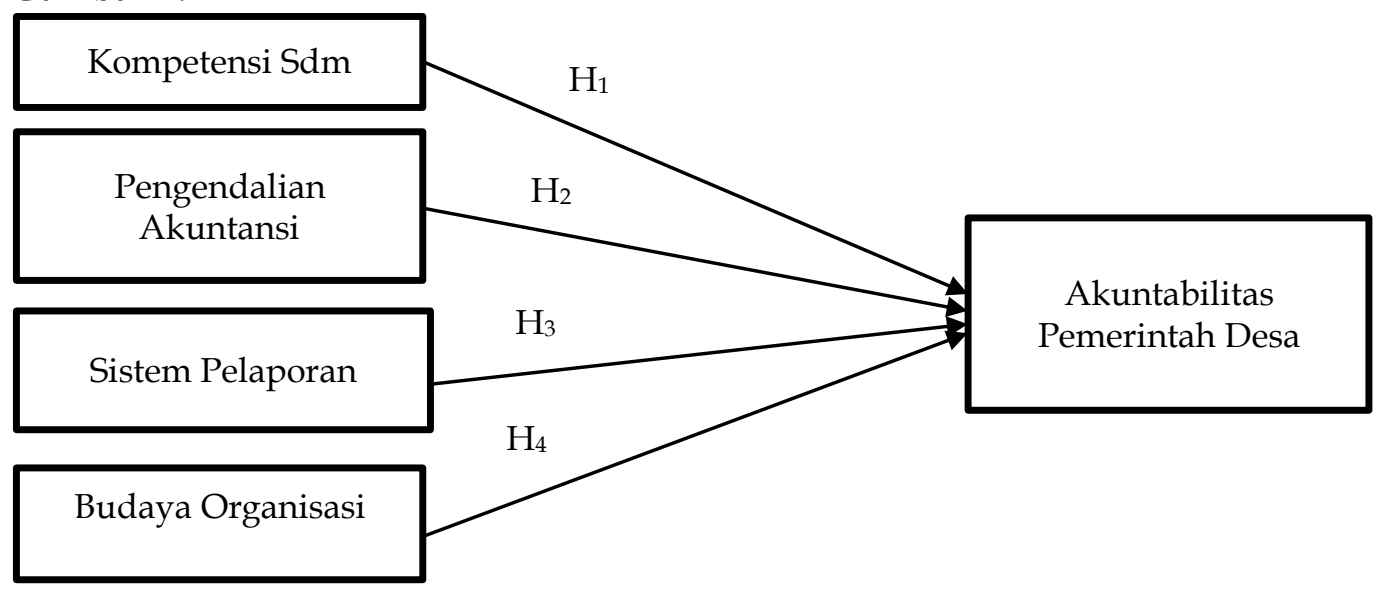

Gambar 1. Model Peneltian

Sumber: Data Penelitian, 2019

\section{METODE PENELITIAN}

Jenis penelitian yang digunakan adalah penelitian asosiatif. Penelitian dilakukan di desa-desa Kecamatan Lingsar, Kabupaten Lombok Barat, Nusa Tenggara Barat pada tahun 2019. Pemilihan Kecamatan Lingsar sebagai lokasi penelitian 
didasarkan pada fenomena yang ada di kecamatan lingsar bahwa akuntabilitasnya masih rendah, sehingga diperlukan upaya untuk meningkatkan akuntabilitas kinerja di kecamatan lingsar. Populasi dalam penelitian ini adalah 11 Desa yang ada di Kecamatan Lingsar Kabupaten Lombok. Teknik pengambilan sampling jenuh atau sensus. Sampel pada penelitian ini adalah seluruh populasi yang ada yaitu sebanyak 60 aparatur. Populasi dan sampel adalah semua perangkat kerja yang memiliki jabatan fungsional dan memiliki wewenang untuk pengambilan keputusan pada Kantor Desa yaitu Kepala Desa, Sekretaris Desa, Bendahara Desa, Badan Permusywaratan Desa dan Kepala Seksi di kantor Desa . Daftar sampel dapat dilihat pada Tabel 1.

\section{Tabel 1. Sampel Penelitian}

\begin{tabular}{llc}
\hline No & Nama Satuan Kerja & Populasi/Sampel \\
\hline 1 & Batu Kumbung & 4 \\
2 & Batu Mekar & 4 \\
3 & Bug-Bug & 4 \\
4 & Dasan Geria & 4 \\
5 & Duman & 4 \\
6 & Gegelang & 4 \\
7 & Gegerung & 4 \\
8 & Giri Madia & 4 \\
9 & Gontoran & 4 \\
10 & Karang Bayan & 4 \\
11 & Langko & 4 \\
12 & Lingsar & 4 \\
13 & Peteluan Indah & 4 \\
14 & Saribaye & 4 \\
15 & Sigerongan & 4 \\
& & 60 \\
\hline
\end{tabular}

Sumber: Data Penelitian, 2019

Akuntabilitas kinerja merupakan salah satu kunci bagi terwujudnya good governance dalam pengelolaan organisasi publik, jika siklus akuntansi sektor publik diakhiri dengan proses pertanggungjawaban publik, proses inilah yang menentukan penilaian keberhasilan organisasi publik dalam mencapai tujuannya. Indikator yang diukur untuk menilai Akuntabilitas Kinerja adalah (1) perencanaan kinerja, (2) pengukuran kinerja, (3) pelaporan kinerja, (4) evaluasi internal, (5) capaian kinerja, dan (6) pemanfaatan informasi kinerja. Instrument yang digunakan untuk mengukur Akuntabilitas Kinerja ini diadopsi dari penelitian Sari (2017).

Kompetensi Sumber Daya Manusia adalah Kemampuan kerja setiap perangkat desa yang mencakup aspek pengetahuan, keterampilan dan sikap kerja yang sesuai dengan standar yang ditetapkan. Indikator yang diukur untuk menilai Kompetensi Sumber Daya Manusia adalah: (1) pengetahuan, (2) kemampuan untuk meningkatkan pengetahuan, (3) keahlian teknis, (3) kemampuan untuk mencari solusi. Instrument yang digunakan untuk mengukur Kompetensi Sumber Daya Manusia ini diadopsi dari penelitian Afriska (2007). 
Pengendalian Akuntansi adalah suatu perencanaan, sistem pelaporan dan prosedur monitor yang didasarkan pada sistem informasi untuk meyakinkan bahwa hasil yang dicapai sesuai dengan rencananya. Indikator yang diukur untuk menilai Pengendalian Akuntansi adalah: Integritas data, Ketepatan input dan posting data, Prosedur otorisasi dokumen transaksi, Tersimpannya dokumen sumber data, Pembagian tanggungjawab, Penentuan kebijakan dan standar akuntansi, Implementasi kebijakan dan standar. Instrument yang digunakan untuk mengukur Pengendalian Akuntansi ini diadopsi dari penelitian Sari (2017).

Sistem Pelaporan adalah sistematik dari berbagai aktivitas, alat, dan prosedur yang dirancang untuk tujuan penetapan dan pengukuran, pengumpulan data, pengklasifikasian, pengikhtisaran, dan pelaporan kinerja pada instansi pemerintah. Indikator yang diukur untuk menilai Sistem Pelaporan adalah: Memiliki manfaat umpan balik (feedback value), Memiliki manfaat prediktif (predictive value), Tepat waktu, Lengkap dan penyajiannya jujur, Dapat dibandingkan, dapat dipahami, netral dan tidak ditutup-tutupi, Keterampilan akuntansi yang baik dalam penyusunan laporan keuangan desa. Instrument yang digunakan untuk mengukur Sistem Pelaporan ini diadopsi dari penelitian Sari (2017).

Budaya Organisasi adalah suatu pola kebiasaan yang terbentuk menjadi aturan yang digunakan sebagai pedoman dalam berfikir dan berperilaku dalam melakukan pekerjaan sebagai cara yang tepat untuk memahami masalahmasalah yang terkait, sehingga akan menjadi sebuah nilai atau aturan dalam suatu organisasi tersebut. Indikator yang diukur untuk menilai Budaya Organisasi adalah, Ketepatan waktu dalam menyelesaikan tugas, Prosedur pelayanan, Penyelesaian masalah. Instrument yang digunakan untuk mengukur Budaya Organisasi ini diadopsi dari penelitian Susanto (2016).

Adapun teknik analisis yang digunakan meliputi analisis deskriptif, uji uji validitas dan reliabilitas, uji asumsi klasik, dan uji hipotesis (Ghozali, 2013). Pengujian hipotesis dilakukan menggunakan analisis regresi linear berganda. Berikut model persamaan regresi dalam penelitian ini sebagai berikut.

$Y=a+b_{1} X_{1}+b_{2} X_{2}+b_{3} X_{3}+b_{4} X_{4}+\varepsilon$

Keterangan:

$Y:$ Akuntabilitas Kinerja Pemerintah Desa
$a:$ Konstanta
$\mathrm{b}:$ Koefisien regresi
$\mathrm{X}_{1}:$ Kompetensi SDM
$\mathrm{X}_{2}:$ Pengendalian Akuntansi
$\mathrm{X}_{3}:$ Sistem Pelaporan
$\mathrm{X}_{4}:$ Budaya Organisasi
$\varepsilon:$ Standar Error pada tingkat 5persen

\section{HASIL DAN PEMBAHASAN}

Pengujian validitas dilakukan dengan melihat nilai Corrected Item-Total Correlation. Jika nilai $r_{\text {hitung }}$ positif dan lebih besar dari $r_{\text {tabel }}$ (pada taraf signifikansi 5 persen atau 0,05), maka data dapat dikatakan valid. Pada penelitian ini menunjukan nilai Corrected Item-Total Correlation nilai $\mathbf{r}_{\text {hitung }}$ positif dan lebih 
besar dari $\mathrm{r}_{\text {tabel }}$ (pada taraf signifikansi 5persen atau 0,05), maka data dinyatakan valid.

Selain itu nilai Cronbatch Alpha untuk masing - masing variabel adalah untuk kompetensi sumberdaya manusia 0,774, pengendalian akuntansi 0,890, sistem pelaporan sebesar 0,847 , budaya organisasi 0,854 dan akuntabilitas kinerja 0,895; ini artinya data untuk semua variabel ini lebih besar dari 0,60, dan dapat disimpulkan bahwa semua variabel pada penelitian ini dapat dikatakan reliabel.

Berdasarkan penjelasan Tabel 2, maka dapat disimpulkan bahwa total skor tertinggi terdapat pada variabel pengendalian akuntansit dan akuntabilitas kinerja pemerintah yakni sebesar 50,00 sementara itu total skor terendah terdapat pada variabel budaya organisasi sebesar 15,00. Skor rata-rata (mean) tertinggi dari data terdapat pada variabel akuntabilitas kinerja pemerintah yakni sebesar 42,29 sedangkan nilai standar deviasi dari akuntabilitas kinerja pemerintahyakni sebesar 3,799. Sementara itu skor rata-rata terendah standar deviasi terdapat pada variabel budaya organisasi sebesar 1,709.

Tabel 2. Statistik Deskriptif

\begin{tabular}{lrrrrr}
\hline & N & Min & Max & Mean & $\begin{array}{c}\text { Std. } \\
\text { Deviation }\end{array}$ \\
\hline Kompetensi SDM & 55 & 24 & 35 & 28,78 & 2,685 \\
Pengendalian akuntansi & 55 & 35 & 50 & 41,02 & 4,166 \\
Sistem pelaporan & 55 & 20 & 30 & 24,89 & 2,719 \\
Budaya organisasi & 55 & 15 & 20 & 17,51 & 1,709 \\
Akuntabilitas kinerja & 55 & 37 & 50 & 42,29 & 3,799 \\
Pemerintah & & & & & \\
\hline
\end{tabular}

Sumber: Data Penelitian, 2021

Berdasarkan Tabel 3, menunjukkan bahwa nilai uji F sebesar 0,000 lebih kecil dari 0,05 artinya variabel independen kompetensi sumberdaya manusia, pengendalian akuntansi, sistem pelaporan, dan budaya organisasi mampu memperediksi variabel dependen akuntabilitas kinerja pemerintah desa. Sedangkan nilai adjusted $R^{2}$ besarnya angka koefisien determinasi 0,682 sama dengan 68,2persen. Angka tersebut mengandung arti bahwa kompetensi sumberdaya manusia, pengendalian akuntansi, sistem pelaporan dan budaya organisasi berpengaruh terhadap akuntabilitas kinerja pemerintah desa sebesar 68,2persen dan sisanya dipengaruhi oleh variabel lain.

Tabel 3. Hasil Regresi Linear Berganda

\begin{tabular}{|c|c|c|c|c|c|}
\hline \multirow[t]{2}{*}{ Variabel } & \multicolumn{2}{|c|}{$\begin{array}{l}\text { Unstandardized } \\
\text { Coefficient }\end{array}$} & \multirow[t]{2}{*}{$\mathrm{T}$} & \multirow[t]{2}{*}{ Sig. } & \multirow[t]{2}{*}{ Keterangan } \\
\hline & $\mathrm{B}$ & $\begin{array}{l}\text { Std. } \\
\text { Error }\end{array}$ & & & \\
\hline (Constan) & 5,713 & 3,524 & 1,621 & 0,111 & \\
\hline Kompetensi SDM & 0,131 & 0,152 & 0,860 & 0,394 & Ditolak \\
\hline Pengendalian Akuntansi & 0,492 & 0,109 & 4,524 & 0,000 & Diterima \\
\hline Sistem Pelaporan & $-0,124$ & 0,183 & $-0,678$ & 0,501 & Ditolak \\
\hline Budaya Organisais & 0,899 & 0,253 & 3,558 & 0,001 & Diterima \\
\hline Uji F & & & 0,000 & & \\
\hline Adjusted $\mathrm{R}^{2}$ & & & 0,682 & & \\
\hline $\mathrm{N}$ & & & 55 & & \\
\hline
\end{tabular}

Sumber: Data Penelitian, 2021 
Variabel kompetensi sumberdaya manusia memiliki nilai $t_{\text {hitung }}$ sebesar 0,860 lebih kecil dari $t_{\text {tabel }} 2,01$ atau nilai sig sebesar 0,394 lebih besar dari 0,05, artinya $\mathrm{H} 0$ diterima dan $\mathrm{H} 1$ ditolak. Hasil penelitian ini menunjukkan bahwa kompetensi sumberdaya manusia tidak berpengaruh dan tidak signifikan terhadap akuntabilitas kinerja pemerintah desa di kecamatan lingsar Kabupaten Lombok Barat. Artinya kompetensi sumberdaya manusia tidak memberikan dampak positif pada peningkatan akuntabilitas kinerja pemerintah desa, sehingga pertanggung jawaban setiap pekerjaan atau program yang dilakukan pemerintah desa bukan dilihat dari bagusnya tingkat SDM akan tetapi dilihat dari behavior atau perilaku seseorang.Kompetensi aparatur merupakan aspek pribadi dari seorang pekerja yang memungkinkan seseorang mencapai kinerja yang baik. Aspek-aspek pribadi ini mencakup sifat, motif, sistem nilai, sikap, pengetahuan dan keterampilan dimana kompetensi akan mengarahkan tingkah laku, sedangkan tingkah laku akan menghasikan kinerja. Penelitian ini mendukung hasil penelitian Arif \& Diarespati, (2017) mengenai Pengaruh Kompetensi dan Sistem Pengendalian Internal Terhadap Akuntabilitas Pemerintah Desa dalam Mengelola Alokasi Dana Desa (ADD). Hasil penelitiannya menyatakan bahwa kompetensi aparatur dari Pemerintah Desa secara signifikan tidak mempengaruhi akuntabilitas pengelolaan keuangan Alokasi Dana Desa (ADD).

Variabel pengendalian akuntansi memiliki nilai thitung sebesar 4,524 lebih besar dari $t_{\text {tabel }} 2,01$ atau nilai sig sebesar 0,000 lebih kecil dari 0,05, artinya H0 ditolak dan H2diterima. Hal ini menjelaskan bahwa pengendalian akuntansi berpengaruh positif dan signifikan terhadap akuntabilitas kinerja pemerintah desadi kecamatan lingsar Kabupaten Lombok Barat. Hasil penelitian ini menunjukkan bahwa sistem pelaporan tidak berpengaruh positif dan signifikan terhadap akuntabilitas kinerja pemerintah desa. Jika laporan yang dibuat aparatur pemerintah desa baik akan menyebabkan pertanggung jawaban yang baik juga. Laporan yang dibuat aparatur pemerintah desa harus andal dan relevan. Jika laporan yang buat tidak baik, maka pertanggungjawaban setiap program yang dilaksanakan akan tidak baik pula. Penelitian ini sejalan dengan hasil penelitian Andreas dan Rusli (2013) yaitu Pengujian kejelasan sasaran anggaran, pengendalian akuntansi dan sistem pelaporan Terhadap Akuntabilitas Kinerja Pemerintah. Hasil penelitiannya menyatakan sistem pelaporan yang dimiliki oleh pemerintah daerah tidak berperan dalam meningkatkan akuntabilitas kinerjanya. Hal ini disebabkan oleh adanya kondisi di mana pemerintah daerah belum mampu memaksimalkan sistem pelaporan yang tersedia untuk mengembangkan akuntabilitas kinerjanya menjadi lebih baik lagi.

Variabel sistem pelaporan memiliki nilai $t_{\text {hitung }}$ sebesar $-0,678$ lebih kecildari $t_{\text {tabel }}$,01 atau nilai sig sebesar 0,501 lebih besar dari 0,05, artinya H0 diterima dan H3ditolak. Hal ini menjelaskan bahwa pengendalian akuntansi tidak berpengaruh positif dan tidak signifikan terhadap akuntabilitas kinerja pemerintah desadi kecamatan lingsar Kabupaten Lombok Barat. Pengendalian akuntansi bermanfaat dalam mengukur, mengevaluasi akuntabilitas kinerja dan dapat memotivasi manejer unit bisnis dalam mencapai tujuan yang telah di tetapkan (Bastian, 2011:459). Pengendalian akuntansi diperlukan untuk pengambilan keputusan operasi agar akuntabilitas kinerja yang diharapkan 
dapat meningkat (Darma 2004). Pengendalian intern akuntansi adalah tentang Pedoman Pengelolaan Keuangan Daerah merupakan proses yang dirancang untuk memberikan keyakinan yang memadai mengenai pencapaian tujuan pemerintah daerah yang tercermin dari keterandalan laporan keuangan, efisiensi dan efektivitas pelaksanaan program dan kegiatan serta dipatuhinya peraturan perundang-undangan (Permendagri No. 13 Tahun 2006). Hasil penelitian ini menunjukkan bahwa pengendalian akuntansi berpengaruh positif dan signifikan terhadap akuntabilitas kinerja pemerintah desa. Apabila pengendalian akuntansi baik akan menyebabkan akuntabilitas kinerja baik juga, setiap pertanggungjawaban yang dilaporkan oleh pemerintah desa tidak terlepas juga dengan pertanggung jawaban dari sisi keuangan sehingga peran pengendali akuntansi dalam hal ini sangat mendukung terciptanya pertanggung jawaban yang baik. Penelitian ini sejalan dengan penelitian Indraswari, (2010) dan Setiawan et al., (2014) menyimpulkan bahwa pengendalian akuntansi berpengaruh positif dan signifikan terhadap akuntabilitas kinerja instansi pemerintah, dimana pengendalian adalah proses yang dilakukan dalam manajemen organisasi untuk menjamin bahwa sumber daya digunakan secara ekonomis, efisien dan efektif.

Variabel budaya organisasi memiliki nilai thitung sebesar 3,558 lebih besar dari $t_{\text {tabel }} 2,01$ atau nilai sig sebesar 0,001 lebih kecil dari 0,05, artinya H0 ditolak dan $\mathrm{H} 4$ diterima. Hal ini menjelaskan bahwa budaya organisasi berpengaruh positif dan signifikan terhadap akuntabilitas kinerja pemerintah desadi kecamatan lingsar Kabupaten Lombok Barat. Budaya organisasi yang baik tentunya akan mempengaruhi kualitas pelayanan publik yang baik pula. Hal ini sesuai dengan pendapat Fandy, (2000), yang mengemukakan bahwa kualitas pelayanan sendiri sebenarnya dipengaruhi oleh banyak aspek salah satunya adalah budaya organisasi dan cara pengorganisasiannya. Dalam organisasi tentunya banyak faktor yang mempengaruhi seseorang untuk mencapai tujuannya, sedangkan jalannya organisasi dipengaruhi oleh perilaku banyak individu yang memiliki kepentingan masing-masing. Oleh sebab itu, budaya organisasi sangat penting, karena merupakan kebiasaan-kebiasaan yang ada dalam organisasi. Kebiasaan-kebiasaan yang baik ini di harapkan dapat meningkatkan kinerja pada organisasi. Hasil penelitian ini sejalan dengan Nurviasari \& Riharjo, (2016) hasil penelitiannya mengemukakan bahwa budaya organisasi berpengaruh positif terhadap akuntabilitas kinerja instansi Pemerintah Kota Surabaya. Hasil penelitian ini mendukung penelitian yang dilakukan Nurkhamid, (2008) menunjukkan bahwa budaya organisasi berpengaruh positif terhadap pengembangan sistem pengukuran kinerja, akuntabilitas kinerja dan penggunaan informasi kinerja. Artinya semakin baik budaya organisasi maka semakin baik pula kinerja yang dicapai. Sehingga budaya organisasi dapat mempengaruhi cara karyawan dalam bertingkah laku, cara menggambarkan pekerjaan, dan cara bekerja dengan karyawan lain. Dalam setiap instansi pemerintah, budaya organisasi selalu diharapkan baik karena baiknya budaya organisasi akan berhubungan dengan berhasil tidaknya instansi pemerintah agar mencapai tujuannya. 


\section{SIMPULAN}

Berdasarkan hasil penelitian dan pengujian hipotesis yang dilakukan maka dapat diambil beberapa kesimpulan bahwa kompetensi sumber daya manusia tidak berpengaruh signifikan terhadap akuntabilitas kinerja pemerintah. Artinya kompetensi sumberdaya yang baik belum mampu meningkatkan akuntabilitas kinerja pemerintah. Hal ini disebabkan oleh rendahnya pemahaman aparaturdesatentang akuntabilitas dan aparatur desa di dominasi lulusan Sekolah Menengah Atas (SMA). Hipotesis kedua pengendalian akuntansi berpengaruh positif dan signifikan terhadap akuntabilias kinerja pemerintah. Artinya semakin tinggi pengendalian akuntansi maka semakin tinggi akuntabilitas kinerja pemerintah. Hal ini menunjukkan bahwa sistem pengendalian akuntansi memberikan dampak baik terhadap akuntabilitas. Sistem Pelaporan Akuntansi tidak berpengaruh signifikan terhadap Akuntabilitas. Artinya akuntabilitas tidak dipengaruhi oleh system pelaporan akuntansi. Hal ini disebabkan karena tidak semua anggota organisasi terlibat dalam proses penyusunan anggaran dan karena kurangnya rasa bekerjasama dari seluruh komponen organisasi untukbersama-sama melaksanakan tugas pokok yang telah ditetapkan. Sedangka budaya organisasi berpengaruh positif dan signifikan terhadap Akuntabilias. Hal ini menunjukkan bahwa budaya organisasi memberikan dampak baik terhadap akuntabilitas. Artinya Semakin baik budaya organisasi maka akan meningkatkan akuntabilitas pemerintah desa.

Penelitian ini memiliki keterbatasan yang dapat diperbaiki pada penelitian selanjutnya. Keterbatasan yang harus dicermati dan saran terhadap keterbatasan yang ditemui oleh peneliti dalam penelitian, antara lain: ruang lingkup penelitian ini hanya dilakukan pada desa-desa di Kecamatan Lingsar Kabupaten Lombok Barat sehingga generalisasi hasil temuan dan rekomendasi penelitian ini kurang dapat diberlakukan bagi desa. Oleh karena itu untuk mendapatkan kesimpulan yang bersifat umum perlu dilakukan penelitian yang lebih luas, serta penelitian ini hanya mengandalkan besaran jumlah responden padahal mestinya berdasarkan banyaknya observasi (desa).

Selama proses penelitian disarankan untuk dapat dipertimbangkan penelitian mendatang yaitu penelitian selanjutnya dapat mengembangkan hasil penelitian dengan menambahkan obyek penelitian, seperti desa-desa se-Provinsi NTB, penelitian mendatang diharapkan dapat mengembangkan instrument penelitian yang lebih baik dengan mengumpulkan referensi terkait penelitian sejenis, dengan demikian diharapkan dapat diperoleh pemahaman yang lebih baik tentang akuntabilitas dan penelitian selanjutnya dapat mengembangkan variabel penelitian, tidak hanya pada variabel, kompetensi sumber daya manusia, pengendalian akuntansi, system pelaporan dan budaya organisasi.

\section{REFERENSI}

Anjarwati, M. (2012). Pengaruh Kejelasan Sasaran Anggaran, Pengendalian Akuntansi, dan Sistem Pelaporan terhadap Akuntabilitas Kinerja Instansi Pemerintah. Accounting Analysis Journal, 1(2), 135-150. https://doi.org/https://doi.org/10.15294/aaj.v1i2.555

Arif, L. N., \& Diarespati. (2017). Pengaruh Kompetensi dan Sistem Pengendalian 
Internal Terhadap Akuntabilitas Pemerintah Desa dalam Mengelola Alokasi Dana Desa (ADD). Berkala Akuntansi Dan Keuangan Indonesia, 2(2), 1-20. https://doi.org/http://dx.doi.org/10.20473/baki.v2i2.4762

Bastian, I. (2011). Sistem Akuntansi Sektor Publik. In Jakarta: Salemba Empat.

Fandy, T. (2000). Manajemen Jasa Edisi Kedua. Andy Offset.

Frink, D. D., \& Klimoski, R. J. (2004). Advancing accountability theory and practice: Introduction to the human resource management review special edition. Human Resource Management Review, 14, 1-17.

Ghozali, I. (2013). Aplikasi Analisis Multivariate Dengan Program IBM SPSS 21 (Edisi Tujuh). In Badan Penerbit Universitas Diponegoro.

Hidayattullah, A., \& Herdjiono, I. (2015). Pengaruh Kejelasan Sasaran Anggaran, Pengendalian Akuntansi, Sistem Pelaporan Terhadap Akuntabilitas Kinerja Skpd Di Merauke. Prosiding Seminar Nasional Multi Disiplin Ilmu \& Call For Papers Unisbank (Sendi_U).

Indraswari. (2010). Pengaruh Kejelasan Sasaran Anggaran, Pengendalian Akuntansi Dan Sistem Pelaporan Terhadap Akuntabilitas Kinerja Instansi Pemerintah Provinsi Jawa Tengah. Universitas Diponegoro, 6(7), 57-69.

Makalalag, A. J., Nangoi, G. B., \& Karamoy, H. (2017). Astri Juainita Makalalag, Grace B Nangoi, Herman Karamoy. Jurnal Riset Akuntansi Dan Auditing "Goodwill," $8(1)$, 150158. https://doi.org/https://doi.org/10.35800/jjs.v8i1.15334

Mardiasmo, (2009). Akuntansi Sektor Publik. Yogyakarta : ANDI

Mudrajad, Kuncoro. (2013). Metode Riset untuk Bisnis dan Ekonomi. Edisi 4. Jakarta: Erlangga.

Nurkhamid, M. (2008). Implementasi Inovasi Sistem Pengukuran Kinerja Instansi Pemerintah. Jurnal Akuntansi Pemerintah, 3(1), 45-75.

Nurviasari, R., \& Riharjo, I. B. (2016). Pengaruh Sistem Informasi, Komitmen Manajemen, Budaya Organisasi Terhadap Akuntabilitas Kinerja Instansi Pemerintah. Jurnal Ilmu Dan Riset Akuntansi, 5(4), 246-260. http://jurnalmahasiswa.stiesia.ac.id/index.php/jira/article/view/1701

Presiden Republik Indonesia Peraturan Pemerintah Nomor 58 Tahun 2005 tentang Pengelolaan Keuangan Daerah

Peraturan Presiden Republik Indonesia Nomor 29 Tahun 2014 tentang Sistem Pengendalian Intern Pemerintah.

Peraturan Menteri Pendayagunaan Aparatur Negara dan Reformasi Birokrasi Nomor 12 Tahun 2015 tentang Pedoman Evaluasi Atas Implementasi Sistem Akuntabilitas Kinerja Instansi Pemerintah.

Sarifudin, M., Kalangi, L., \& Gamaliel, H. (2017). Pengaruh Kompetensi Aparat Pengelola Dana Desa, Komitmen Organisasi Pemerintah Desa, dan Partisipasi Masyarakat Terhadap Akuntabilitas Pengelolaan Dana Desa Di Kabupaten Gorontalo. Jurnal Riset Akuntansi Dan Auditing "Goodwill," 4(1), 123-140. https://doi.org/https://doi.org/10.35800/jjs.v8i2.17199

Setiawan, E., Andreas, \& Rusli. (2014). Pengaruh Kejelasan Sasaran Anggaran, Pengendalian Akuntansi dan Sistem Pelaporan terhadap Akuntabilitas Kinerja Instansi Pemerintah. Jurnal Online Mahasiswa (JOM) Bidang Ilmu Ekonomi, 1(1). https://doi.org/2355-66854

Sekaran. (2013). Metodologi Penelitian untuk Bisnis. Jakarta : Salemba Empat 
Sugiyono. (2014). Statistika untuk Penelitian. Bandung: Alfabeta,

Sugiyono. (2013). Metode Penelitian Kuantitatif Kualitatif dan RED. Bandung : Alfabeta

Sugiyono. (2001). Metode Penelitian. Bandung : Alfabeta

Ulum, Ihyaul. (2010). Akuntansi Sektor Publik.Yogyakarta : Graha Ilmu.

Wahyuni, Raja Adri Satriawan Surya \& Enni Savitri. (2013). Pengaruh Kejelasan Sasaran Anggaran, Pengendalian Akuntansi Dan Sistem Pelaporan Terhadap Akuntabilitas Kinerja Instansi Pemerintah. Universitas Riau, 3 (2): 52-72.

Zirman, E. D., \& Rozi R. M. (2010) Pengaruh Kompetensi Aparatur Pemerintah Daerah, Penerapan Akuntabilitas Keuangan,Motivasi Kerja, Dan Ketaatan Pada Peraturan Perundangan Terhadap Akuntabilitas Kinerja Instansi Pemerintah. Universitas Riau, 2 (3): 155-174.

Zulharman K. (2015). Pengaruh Penerapan Sistem Akuntansi Pemerintah Daerah, Pemahaman Akuntansi, Dan Ketaatan Pada Peraturan Perundangan Terhadap Akuntabilitas Kinerja Instansi Pemerintah. Universitas Riau, 1 (2): 82-97. 